\title{
Brain-derived neurotrophic factor gene polymorphism in post-ST-elevation myocardial infarction patients undergoing primary percutaneous intervention
}

\author{
Olga V. Petyunina ${ }^{1 \oplus}$, Mykola P. Kopytsya ${ }^{2 \oplus}$, Alexander E. Berezin ${ }^{3, * \odot}$
}

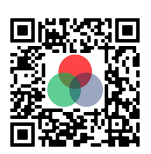

Use your smartphone to scan this QR code and download this article

${ }^{1} \mathrm{MD}, \mathrm{PhD}$, Senior researcher of department of prevention and treatment of emergency conditions, Government Institution "L.T.Malaya Therapy National Institute NAMSU", 2 A Liubovi Maloy av., 61039, Kharkiv, Ukraine

${ }^{2} \mathrm{MD}, \mathrm{PhD}$, Professor, Chief of Department of prevention and treatment of emergency conditions, Government Institution "L.T.Malaya Therapy

National Institute NAMSU”, 2A Liubovi Maloy av., 61039, Kharkiv, Ukraine

${ }^{3}$ Professor, MD, PhD, Senior Consultant of Therapeutic Unit, Internal Medicine Department, State Medical University of Zaporozhye, 26, Mayakovsky av., Zaporozhye, 69035, Ukraine

\section{Correspondence}

Alexander E. Berezin, Professor, MD PhD, Senior Consultant of Therapeutic Unit, Internal Medicine Department, State Medical University of Zaporozhye, 26, Mayakovsky av., Zaporozhye, 69035, Ukraine

Email: aeberezin@gmail.com

History

- Received: Jul 03, 2020

- Accepted: Aug 22, 2020

- Published: Aug 31, 2020

DOI : 10.15419/bmrat.v7i8.622

\section{Check for updates}

\section{Copyright}

(c) Biomedpress. This is an openaccess article distributed under the terms of the Creative Commons Attribution 4.0 International license.

\begin{abstract}
Introduction:The goal of this study was to elucidate a link of brain-derived neurotrophic factor (BDNF) Val66Met gene with combined 6-month clinical end points in post-myocardial infarction patients. Methods: 256 post-myocardial infarction patients who underwent primary percutaneous coronary intervention were enrolled in the study. Variants of Val66Met gene BDNF were identified by real-time polymerase chain reaction at baseline. Results: The combined clinical end points (major cardiovascular events and hospitalization) were determined in 61 (23.8\%) post-STEMI patients; consequently, 195 (76.2\%) patients did not meet the events. Univariate linear regression revealed that predictors for combined clinical end points were peak Tnl levels, NT-proBNP, SYNTAX score, TIMI score, obesity, left ventricular ejection fraction, and genotype 66ValMet+66MetMet in BDNF gene. The cumulative clinical outcomes (major adverse cardiac events and admission) were determined in 61 (23.8\%) patients. Kaplan-Meier curves demonstrated that 66ValVal genotype of BDNF gene was significantly associated with the low number of combined end points. Conclusion: The Val66Met polymorphism in BDNF gene independently predicted 6-month combined clinical end points in post-myocardial infarction patients.
\end{abstract}

Key words: ST-segment elevation myocardial infarction, single nucleotide polymorphism Val66Met, brain derived neurotrophic factor, outcomes

\section{INTRODUCTION}

Recurrent major adverse cardiac events (MACEs) and heart failure (HF) remain the most common causes of premature cardiovascular (CV) mortality amid post-ST-segment elevation myocardial infarction (STEMI) patients, regardless of wide implementation of early re-vascularization strategies including primary percutaneous coronary intervention $(\mathrm{PPCI})^{1,2}$. In fact, conventional pure approaches based on clinical assessment, transthoracic echocardiography and biomarkers of myocardial necrosis are insufficient today to catch vulnerable post-STEMI patients after successful PPCI ${ }^{3}$. Although there are several biomarkers (natriuretic peptides, high sensitive cardiac troponins, soluble ST2, etc.) that are designed for risk stratification among patients with STEMI ${ }^{4-6}$, the risk assessment and prediction of poor clinical outcomes after successful competed PPCI in postSTEMI patients are uncertain ${ }^{7}$. There are several limitations that could decrease the predictive value of conventional biomarkers in post-STEMI individuals, such as older age, morbid obesity, diabetes mellitus (DM), preserved or normal left ventricular (LV) ejection fraction (EF), co-existing kidney insufficiency and atrial fibrillation ${ }^{8-10}$.

Neurotrophins are a superfamily of regulatory proteins which regulate proliferation, differentiation, survival and plasticity of neurons ${ }^{11}$. Brain-derived neurotropic factor (BDNF) was previously found as one of the neurotrophins with proliferative, cholinergic, serotoninergic and dopaminergic activities, and is predominantly synthesized in central and peripheral neurons $^{12}$. Later, an expression of mRNA BDNF was found in myocardium, vessel vasculature, skeletal muscles, parenchymal organs (including lung, spleen and kidney), visceral epithelial cells, and mature and progenitor endothelial cells ${ }^{13-15}$. Previous animal and clinical studies have revealed that BDNF through an activation of nuclear factor $\mathrm{kB}$ receptors mediates endothelial cell survival and neoangiogenesis, reduces p75-mediated apoptosis of cardiac myocytes, enhances endothelial function, regulates blood flow in ischemic myocardium, and improves LV function after ischemic injury, thereby providing cardioprotective effects ${ }^{16,17}$.

Observational and clinical investigations have shown strong inverted associations between BNDF levels in peripheral blood and cognitive dysfunction in $\mathrm{HF}$ 
patients, and $\mathrm{CV}$ risk in individuals with known $\mathrm{DM}$, hypertension, cardiomyopathy, stable coronary artery disease and STEMI ${ }^{18-21}$. However, circulating levels of BDNF exhibited a close correlation with single nucleotide polymorphism (SNP) in BDNF gene that was associated with a replacement of valine to methionine in the 66 position of codon (Val66Met). It has been suggested that this SNP Val66Met affects the intracellular processing of the peptide and leads to a decline in the secretion of BDNF, resulting in lowered susceptibility to ischemia and myocardial injury ${ }^{22,23}$. The aim of the study was to elucidate a link of BDNF Val66Met gene with cumulative 6-month clinical end points in post-myocardial infarction patients.

\section{MATERIAL AND METHODS}

\section{Patient population}

From 2016 August to 2019 February, 320 patients underwent selective coronary angiography due to suspected acute STEMI. Acute STEMI was diagnosed in accordance to the European Society of Cardiology (ECS) recommendation (2017) ${ }^{24}$. The study flow chart is shown in Figure 1. We identified 256 acute STEMI individuals who underwent PPCI with an implantation of bare-metal stent "COMMANDER" manufactured by "Alvimedica" (Turkey) in culprit artery ( 1 to 4 stents onto ischemic-related arteries) and discharged with post-PPCI TIMI III score from the hospital. All patients were treated with current adjuvant care ${ }^{24}$.

\section{Coronary angiography}

We used radial or femoral vascular access and twoto-three orthogonal projections to receive angiograms at baseline. A digital X-ray system "Integris Allura9" (Philips Healthcare, Eindhoven, Netherlands) was used to visualize coronary anatomyto visualize coronary anatomy. Ultravist-370 (Baier Pharma, GmbH, Germany) was the contrast giving automatically through the injector.

\section{Ethical declaration}

All patients enrolled in the study gave voluntary informed consent to participate. The study was approved by the local ethics committee (Protocol №8, 29.08.2016). The study had been carried out in accordance with the 1964 Helsinki declaration.

\section{Sample size calculation}

We calculated sample size by taking into consideration the effect size estimation (0.99), type II error (0.2), type I error (0.05), expected mortality rate of
$7 \%$, and one-year mortality rate of $14 \%{ }^{25}$. The sample size was 250 individuals.

\section{Determination of risk factors and co- morbidities}

$\mathrm{DM}$ was diagnosed as serum level of fasting glucose of $>7.0 \mathrm{mmol} / \mathrm{L}, 2$ - $\mathrm{h}$ postprandial glucose serum level of $>11.1 \mathrm{mmol} / \mathrm{L}$, or current therapy of anti-diabetic drugs $^{26}$. Hypercholesterolemia (HCE) hypertension was diagnosed in accordance with current recommendation $^{27,28}$. HF was diagnosed according to current ECS clinical guidelines ${ }^{29}$. Information of other diseases and medical history were obtained by investigators through a review of medical history or direct contact with the patient's general practitioner.

\section{Echocardiography examination}

Transthoracic B-mode echocardiography and Tissue Doppler Imaging were carried out using $3.5 \mathrm{MHz}$ phase probe with "Aplio 500" (TUS-A500, Toshiba Inc., Japan) at baseline. LVEF were measured by Simpson's method. LV global longitudinal strain (ec) and early transmitral velocity (E) were measured by tissue Doppler imaging technique and impulse transmitral Doppler regime, respectively.

\section{Determination of STEMI prognosis}

We used the TIMI score and the GRACE score to validate prognostic capacity after STEMI ${ }^{30,31}$.

\section{SYNTAX score determination}

SYNTAX score (SS) was calculated by an experienced interventional cardiologist accordingly ${ }^{32}$.

\section{Determination of endpoints}

The primary endpoint was MACEs in combination with hospitalization that occurred during 6-month period post-discharge period. MACEs included CV death, recurrent angina, and newly diagnosed HF. The endpoint was ascertained by personal or phone contact with a general practitioner or staff of the hospital in which the patient had been admitted.

\section{Calculation of glomerular filtration rate}

The Chronic Kidney Disease Epidemiology Collaboration (CKD-EPI) equation was used to calculate glomerular filtration rate $(\mathrm{GFR})^{33}$.

\section{Collection of blood samples}

Venous blood samples were collected from the patients using vacutainers at baseline and at the end of the study. After 30-minute centrifugation, the serum 


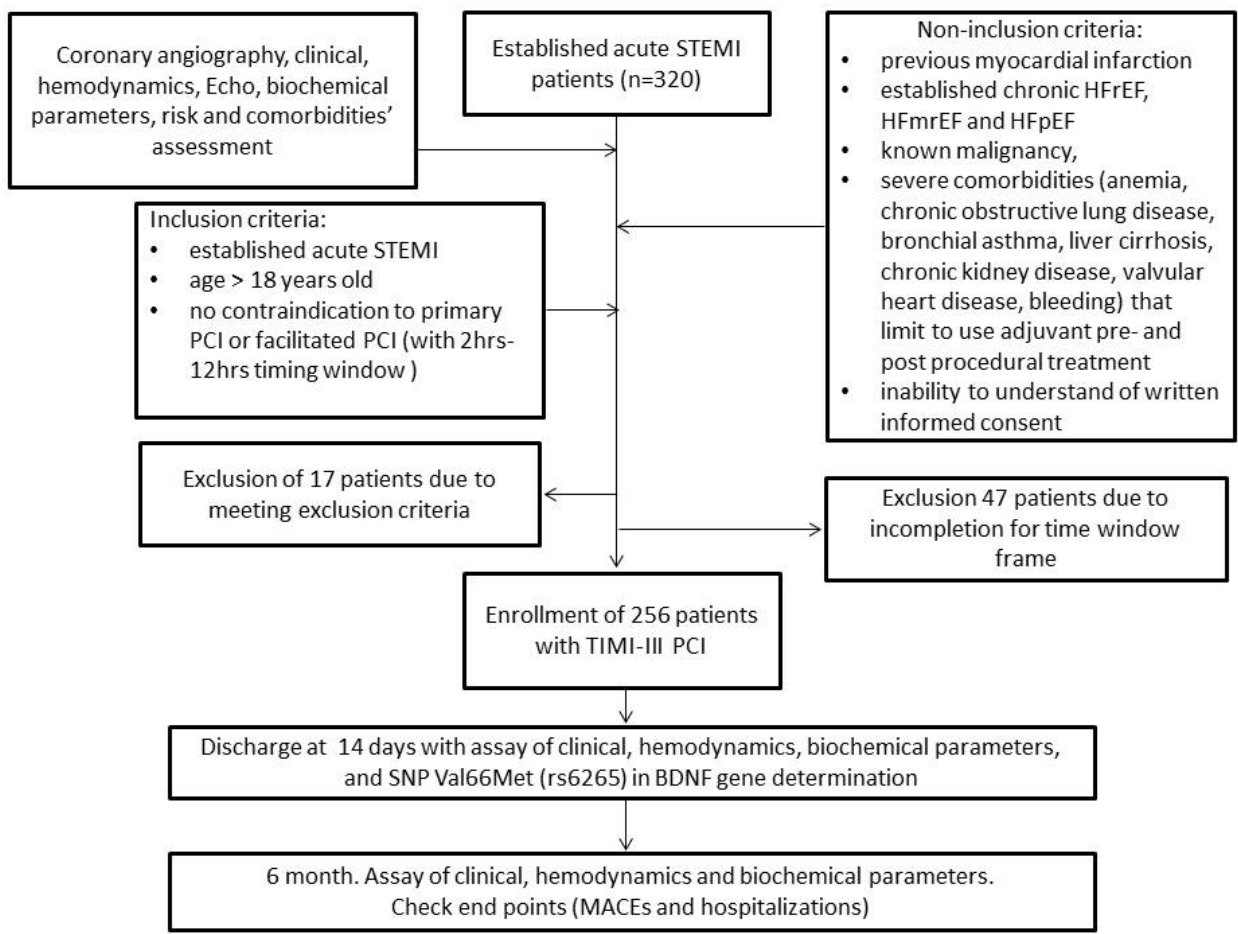

Figure 1: Study design flow chart. Abbreviation: MACE: major adverse cardiac events

was collected and then stored at $-70^{\circ} \mathrm{C}$ until transfer to the laboratory of GI "L.T.Malaya TNI NAMSU". Hematology and biochemistry, including lipid profiles and fasting glucose, were provided for each patient.

Serum levels of troponin I (TnI) were measured by chemo-luminescent immunoassay method on the biochemical analysator (Humalyser 2000, Mannheim, Germany). The average of the TnI level was 0.5-50 $\mathrm{ng} / \mathrm{mL}$.

$\mathrm{N}$-terminal fragment of brain natriuretic peptide (NT-proBNP) was evaluated by use of a commercially available kit manufactured by R\&D Systems $\mathrm{GmbH}$ (Wiesbaden-Nordenstadt, Germany). The average of the NT-proBNP level was $10-12000 \mathrm{pg} / \mathrm{mL}$.

\section{SNP Val66Met (rs6265) in BDNF gene deter- mination}

The extraction of DNA was executed per the conventional protocol for a commercial set (TacMan TMSNP Genotyping Assays; Thermo Fisher Scientific Assay IDC_11592758_1). The BDNF genetic variants were evaluated by real-time polymerase chain reaction (PCR). Primers used in the BDNF Val66Met (rs6265) polymorphism assay were as follows: CCTACAGTTCCACCAGGTGAGAAGAGTG (forward), TCATGGACATGTTTGCAGCATCTAGGTA (reverse).

\section{Statistics}

Baseline characteristics are presented as mean \pm standard deviation (SD) or median (IQR) for continuous variables and proportions for categorical variables. Chi-square test or Mann-Whitney U test and T-test were used to compare the categorical or normallydistributed data, respectively. Hardy-Weinberg Equilibrium was conducted to estimate allele frequencies. Spearman correlation analysis was performed to investigate the relationship between circulating levels of cardiac biomarkers, co-morbidities, and BDNF gene SNP. Univariate and multiple variate linear regression analyses were done; factors that predict the combined endpoint were determined. The beta coefficient, standard error (SE), odds ratio (OR), and 95\% confidence interval (CI) for predictors were evaluated. We also checked whether five common subject-level gene models (recessive, multiplicative, additive, dominant, and over-dominant models) were related to the explanatory variables ${ }^{34}$. We also used area under curve (AUC), integrated discrimination indices (IDI), and net-reclassification improvement (NRI) for prediction performance analyses. Significant differences 
between variables were set at $\mathrm{p}$-value $<0.05$.

\section{RESULTS}

The combined clinical endpoints (MACEs and hospitalization) were determined in $61(23.8 \%)$ postSTEMI patients; consequently, 195 (76.2\%) patients did not meet the events. General clinical characteristics of the entire patient population enrolled in the study and both cohorts (with MACEs and free MACEs) are reported in Table 1 . The entire population consisted of participants with mean age of 58.76 years old, with male/female proportion of $77.3 \% / 22.7 \%$, with CV risk factors including hypertension (52\%), type 2 DM (T2DM) (19.5\%), hypercholesterolemia (63.7\%), obesity (37.5\%), and smoking $(34.9 \%)$. We did not find significant differences between both cohorts of the post-STEMI patients in terms of demographics, glomerular filtration rate, and CV risk factor presentation, except in the incidence of T2DM and hypertension, which were more frequently seen in patients who met MACEs than in individuals who were free of MACEs $(\mathrm{P}=0.032$ and $\mathrm{P}=0.0008$, respectively). Therefore, participants with MACEs were older that those who did not meet MACEs ( $\mathrm{P}=$ 0.027)

The patients who met MACEs exhibited higher peak serum levels of troponin I and circulating levels of NT-proBNP than those who had no MACEs. Significant differences in lipid profiles among both patient cohorts were not found.

The observed frequency of Val66Met BDNF genotype in post-STEMI patients was as follows: 66ValVal $74.2 \%$ and 66ValMet+66MetMet - 25.8\%. Genotype frequency matched to Hardy-Weinberg equilibrium $\left(\chi^{2}=0.17, \mathrm{P}>0.05\right)$. There were not differences between both cohorts in terms of phenotype of BDNF $(\mathrm{P}=0.272)$.

All post-STEMI patients were treated according to contemporary clinical protocol and there were not significant differences in concomitant medications, except for metformin which was prescribed frequently in the patient cohort with MACEs $(\mathrm{P}=0.046)$. We found that TIMI risk in patients with MACEs was significantly higher in comparison with individuals who had no combined endpoint $(\mathrm{P}=0.046)$ (Table 2). Nevertheless, the number of participants in both cohorts having $22-32$ SYNTAX score points and $\leq 22$ SYNTAX score points did not differ, but the proportion of the patients with MACEs having > 32 SYNTAX score points occurred frequently when compared with those who did not meet the endpoint. Additionally, total GRACE score points were similar in both patient cohorts $(\mathrm{P}=0.294)$.
Significant differences between both cohorts in terms of localization of STEMI were not found, even though one vessel injury frequently occurred in MACEs-free patients. In contrast, patients having MACEs represented frequent circumflex artery injury $(p=0.021)$. Hemodynamic characteristics in post-STEMI patients at baseline are reported in Table 3. The patients having MACEs had lower LVEF $(\mathrm{P}=0.005)$, higher left atrium volume $(\mathrm{P}=0.021)$, and $\mathrm{E} / \mathrm{e}^{\mathrm{r}}$ ratio $(\mathrm{P}=$ 0.042 ) than those who had no MACEs.

\section{Spearman correlation analysis between STEMI severity, circulating levels of cardiac biomarkers, co-morbidities and BDNF gene SNP}

There were statistically significant correlations of circulating levels of NT-pro-BNP with TIMI score ( $\mathrm{r}=$ $-0.33 ; \mathrm{p}=0.001), \mathrm{LVEF}$ at baseline $(\mathrm{r}=-0.42 ; \mathrm{p}=$ $0.003)$, obesity $(r=-0.26 ; p=0.012)$, age $(r=0.27 ; p$ $=0.022)$, and $66 \mathrm{ValVal}$ genotype of BDNF gene $(\mathrm{r}=$ $-0.41 ; \mathrm{p}=0.003)$. The SYNTAX score was inversely correlated with LVEF at baseline $(r=-0.34 ; \mathrm{p}=0.001)$ and 66ValVal genotype of BDNF gene $(r=-0.26 ; p=$ $0.001)$, and positively correlated with T2DM $(r=0.32$; $\mathrm{p}=0.002)$.

\section{Univariate and multivariate linear regres- sions}

Univariate linear regression revealed that predictors for the combined clinical endpoints were peak TnI levels, NT-proBNP, SYNTAX score, TIMI score, obesity, LVEF, and genotype 66ValMet+66MetMet in BDNF gene (Table 4). Unadjusted multivariate linear regression showed that the peak of TnI levels, NT-proBNP, SYNTAX score, TIMI score, and 66ValMet+66MetMet genotype in BDNF gene all remained independent predictors for the combined clinical endpoints. After adjustment for SYNTAX score and TIMI score, genotype 66ValMet+66MetMet in BDNF gene $(\mathrm{OR}=1.5476 ; 95 \% \mathrm{CI}=1.1277-4.1426 ; \mathrm{P}=0.0246)$ and NT-proBNP (OR $=1.7546 ; 95 \%$ CI $=1.0219$ 3.1002; $\mathrm{P}=0.046$ ) independently predicted cumulative clinical endpoint.

\section{Comparison of the predictive abilities of the models}

We compared both models (genotype 66ValMet+66MetMet in BDNF gene and NT-proBNP) for STEMI individuals (Table 5). The genotype 66ValMet+66MetMet in BDNF gene was better than NT-proBNP and standard model, while the only adjusted models were entered in the analysis. 
Table 1: Clinical characteristic of STEMI patients enrolled in the study

\begin{tabular}{|c|c|c|c|c|}
\hline Variables & $\begin{array}{c}\text { Entire STEMI } \\
\text { population }(n= \\
256)\end{array}$ & $\begin{array}{l}\text { Patients who met } \\
\text { MACEs }(n=61)\end{array}$ & $\begin{array}{l}\text { Patients who did not } \\
\text { meet MACEs }(n= \\
\text { 195) }\end{array}$ & $\chi^{2}, \mathbf{p}$ \\
\hline Age, years, M (SD) & $58.76 \pm 9.85$ & $61.07 \pm 9.39$ & $58.13 \pm 10.02$ & 0.027 \\
\hline Male, n (\%) & $198(77.3)$ & $42(68.9)$ & $156(80.0)$ & 0.070 \\
\hline Female, n (\%) & $58(22.7)$ & $19(31.1)$ & $39(20.0)$ & \\
\hline Hypertension, n (\%) & $133(52.0)$ & $39(63.9)$ & $94(48.2)$ & 0.032 \\
\hline T2DM, n (\%) & $50(19.5)$ & $21(34.4)$ & $29(14.9)$ & 0.0008 \\
\hline Smoking, n (\%) & $89(34.9)$ & $27(44.3)$ & $62(31.8)$ & 0.074 \\
\hline HCE, n (\%) & $163(63.7)$ & $42(68.9)$ & $121(62.1)$ & 0.335 \\
\hline $\mathrm{BMI}>30 \mathrm{~kg} / \mathrm{m}^{2}, \mathrm{n}(\%)$ & $96(37.5)$ & $24(39.3)$ & $72(36.9)$ & 0.733 \\
\hline GFR, $\mathrm{ml} / \mathrm{min} / 1.73 \mathrm{~m}^{2}$ & $104.67 \pm 27.56$ & $103.68 \pm 27.77$ & $107.50 \pm 26.96$ & 0.389 \\
\hline \multicolumn{5}{|l|}{ Circulating biomarkers } \\
\hline Peak TnI, ng/ml & $18.4[5.44-87.3]$ & $\begin{array}{c}21.56 \\
{[11.55-99.45]}\end{array}$ & $13.18[5.97-68.5]$ & 0.038 \\
\hline NT-proBNP, pg/mL & $\begin{array}{c}246.81[26.78- \\
610.97]\end{array}$ & $\begin{array}{c}415.12 \\
{[74.45-1305,42]}\end{array}$ & $202.43[54.48-802.60]$ & 0.001 \\
\hline $\mathrm{TC}, \mathrm{mmol} / \mathrm{l}$ & $4.97[4.00-5.75]$ & $5.13[4.26-5.87]$ & $4.89[3.97-5.68]$ & 0.192 \\
\hline $\mathrm{HDL}, \mathrm{mmol} / \mathrm{l}$ & $1.09[0.90-1.28]$ & $1.12[0.94-1.28]$ & $1.08[0.90-1.28]$ & 0.534 \\
\hline LDL, mmol/l & $3.00[2.11-3.71]$ & $3.20[2.45-3.98]$ & $2.86[2.06-3.63]$ & 0.078 \\
\hline $\mathrm{TG}, \mathrm{mmol} / \mathrm{l}$ & $1.53[1.17-2.02]$ & $1.48[1.17-1,83]$ & $1.57[1.17-2.06]$ & 0.455 \\
\hline \multicolumn{5}{|c|}{ SNP polymorphism of BDNF gene } \\
\hline 66ValVal, n (\%) & $190(74.2)$ & $42(68.9)$ & $148(75.9)$ & 0.272 \\
\hline 66ValMet+66MetMet, n (\%) & $66(25.8)$ & $19(31.1)$ & $47(24.1)$ & \\
\hline \multicolumn{5}{|l|}{ Concomitant medications } \\
\hline Beta-blockers, n (\%) & $256(100)$ & $61(100)$ & $195(100)$ & 1.00 \\
\hline ACEI / ARBs, n (\%) & $245(95.7)$ & $58(95.1)$ & $187(95.9)$ & 0.98 \\
\hline Clopidogrel /Ticagrelor, n (\%) & $252(98.4)$ & $58(95.1)$ & $194(99.5)$ & 0.99 \\
\hline Statins, n (\%) & $256(100)$ & $61(100)$ & $195(100)$ & 1.00 \\
\hline MCRAs, n (\%) & $178(69.5)$ & $43(70.5)$ & $135(69.2)$ & 0.94 \\
\hline Metformin, n (\%) & $32(12.5)$ & $10(16.4)$ & $22(11.3)$ & 0.046 \\
\hline Loop diuretics, $\mathrm{n}(\%)$ & $71(27.7)$ & $20(32.7)$ & $51(26.2)$ & 0.12 \\
\hline
\end{tabular}

Abbreviations:

BMI: bodymass index; HCE: hypercholesterolemia; LDL: low-density lipoprotein; HDL: high-density lipoprotein; T2DM: type 2 diabetes mellitus; TG: triglycerides; Tn: cardiac troponin; ACEI: angiotensin-converting enzyme inhibitor; ARBs: angiotensin-II receptor antagonist; MCRA: mineralocorticoid receptor antagonist 
Table 2: STEMI localization and injured coronary arteries in patient population

\begin{tabular}{|c|c|c|c|c|}
\hline Variables & $\begin{array}{c}\text { Entire STEMI } \\
\text { population }(\mathrm{n}= \\
256)\end{array}$ & $\begin{array}{c}\text { Patients who } \\
\text { met MACEs }(\mathrm{n}= \\
61)\end{array}$ & $\begin{array}{l}\text { Patients who did not } \\
\text { meet MACEs }(n= \\
195)\end{array}$ & $\chi^{2}, \mathbf{p}$ \\
\hline \multicolumn{5}{|l|}{ STEMI scores } \\
\hline TIMI risk score, point & $6[4-7]$ & $8[5-9]$ & $6[4-8]$ & 0.046 \\
\hline Total SYNTAX score, point & $28.7 \pm 6.15$ & $27.54 \pm 6.41$ & $25.65 \pm 8.82$ & 0.134 \\
\hline > 32 points, $\mathrm{n}(\%)$ & $76(42.9)$ & $41(54.6)$ & $35(34.3)$ & 0.011 \\
\hline $22-32$ points, $n(\%)$ & $79(44.6)$ & $38(50.7)$ & $41(40.2)$ & 0.167 \\
\hline$\leq 22$ points, $\mathrm{n}(\%)$ & $22(12.4)$ & $10(13.3)$ & $12(11.8)$ & 0.765 \\
\hline Total GRACE Score, points & $150(120-172)$ & $143(117-170)$ & $152(119-176)$ & 0.294 \\
\hline \multicolumn{5}{|l|}{ STEMI localization } \\
\hline Anterior, n (\%) & $126(49.2)$ & $30(49.2)$ & $96(49.2)$ & 0.995 \\
\hline Posterior, n (\%) & $113(44.1)$ & $22(36.1)$ & $91(50.8)$ & \\
\hline Lateral, n (\%) & $17(6.6)$ & $9(14.8)$ & $8(4.1)$ & \\
\hline \multicolumn{5}{|l|}{ Culprit coronary arteries } \\
\hline One vessel injury, n (\%) & 96(37.5) & $15(24.6)$ & $81(41.5)$ & 0.017 \\
\hline Two vessels injury, n (\%) & $69(26.9)$ & $19(31.1)$ & $51(26.2)$ & 0.445 \\
\hline Three and more vessels injury, n (\%) & $70(27.3)$ & $22(36.1)$ & $48(24.6)$ & 0.080 \\
\hline Quantity of stenosis & $2.0[1.0-4.0]$ & $2.0[1.0-4.0]$ & $2.0[1.0-4.0]$ & 1.0 \\
\hline Left anterior descending injury, $\mathrm{n}(\%)$ & $185(72.3)$ & $46(75.4)$ & 139(71.3) & 0.530 \\
\hline Right coronary artery injury, n (\%) & $142(55.5)$ & $42(68.9)$ & $107(54.9)$ & 0.053 \\
\hline Circumflex artery injury, n (\%) & $106(41.4)$ & $33(54.1)$ & $73(37.4)$ & 0.021 \\
\hline Left coronary artery injury, n (\%) & $24(9.4)$ & $8(13.1)$ & $16(8.2)$ & 0.92 \\
\hline
\end{tabular}

Table 3: Hemodynamic characteristics in post-STEMI patients at baseline

\begin{tabular}{lcccc}
\hline Variables & $\begin{array}{c}\text { Entire STEMI } \\
\text { population }(\mathbf{n}=\end{array}$ & $\begin{array}{c}\text { Patients who } \\
\text { met MACEs }(\mathbf{n}=\end{array}$ & $\begin{array}{c}\text { Patients who did } \\
\text { not meet MACEs } \\
(\mathbf{n}=\mathbf{1 9 5})\end{array}$ & P value \\
HR, per minute & $\mathbf{2 5 6 )}$ & $\mathbf{6 1})$ & $76 \pm 15$ & 0.079 \\
Systolic BP, mm Hg & $16 \pm 15$ & $79 \pm 16$ & $138 \pm 25$ & 0.003 \\
Diastolic BP, mm Hg & $80 \pm 12$ & $123 \pm 22$ & $81 \pm 12$ & 0.019 \\
LV EDV, ml & $136 \pm 37$ & $137 \pm 45$ & $136 \pm 35$ & 0.930 \\
LV ESV, ml & $64 \pm 28$ & $69 \pm 36$ & $63 \pm 25$ & 0.516 \\
LVEF, \% & $51 \pm 10$ & $48 \pm 11$ & $52 \pm 10$ & 0.005 \\
LA, cm & $4.10 \pm 0.51$ & $3.68 \pm 0.54$ & $4.04 \pm 0.53$ & 0.477 \\
LAV, ml & $56 \pm 7$ & $57 \pm 10$ & $54 \pm 9$ & 0.021 \\
E/e, unit & $11.6 \pm 4.28$ & $12.89 \pm 5.34$ & $11.31 \pm 4.86$ & 0.042 \\
\hline
\end{tabular}

Abbreviations:

HR: heat rate; LAD: left atrium diameter; LAV: left atrium volume; LVEDV: left ventricular end diastolic volume; LVESV: left ventricular end systolic volume; LVEF: left ventricular ejection fraction; BP: blood pressure 


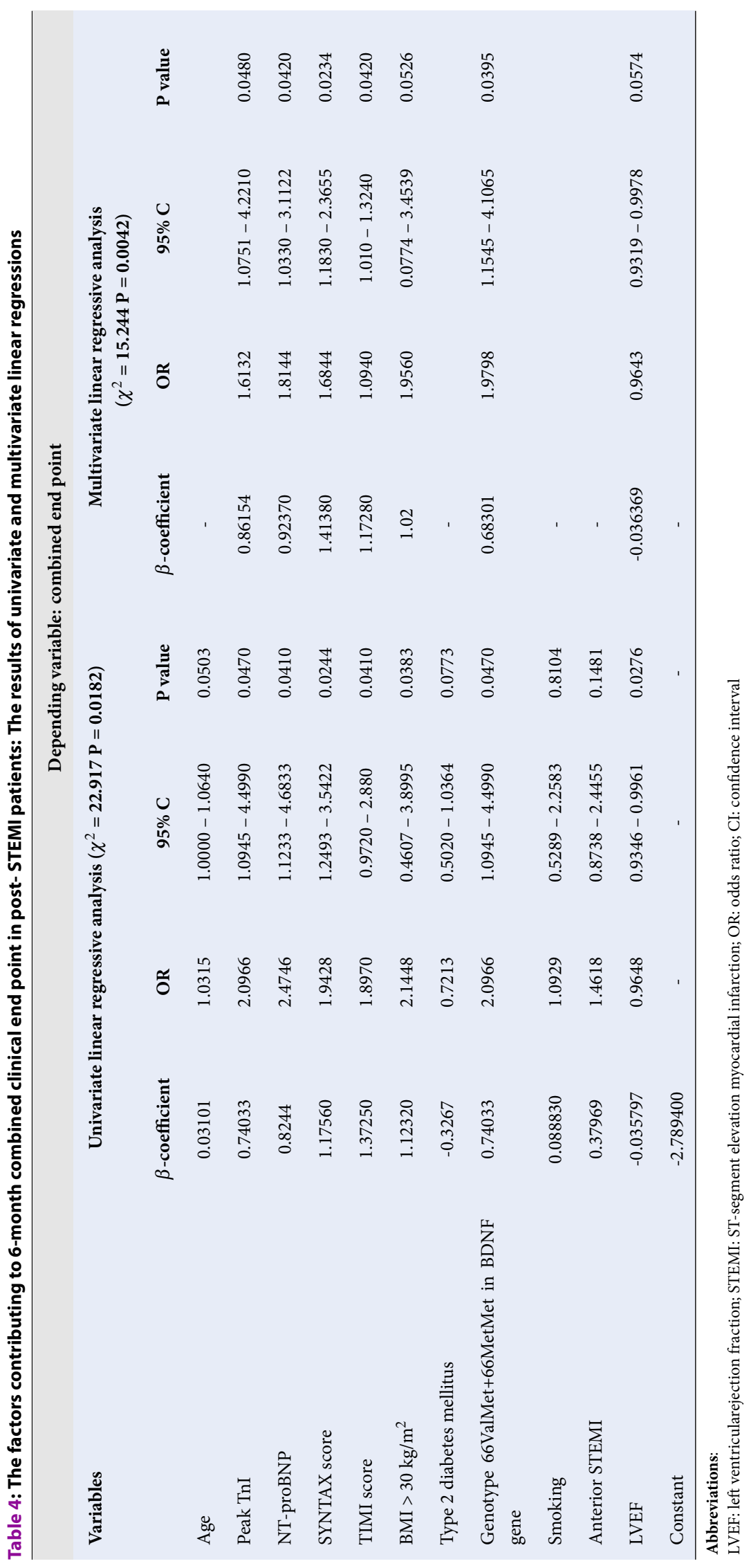


Table 5: Comparisons of predictive models with integrated discrimination indices and net-reclassification improvement

\begin{tabular}{|c|c|c|c|c|c|c|c|c|c|}
\hline \multirow[t]{3}{*}{ Models } & \multicolumn{9}{|c|}{ Depending variable: combined end point } \\
\hline & AUC & & & NRI & & & IDI & & \\
\hline & $\mathbf{M}$ & $\begin{array}{c}95 \% \\
\mathrm{CI}\end{array}$ & $\begin{array}{c}P \\
\text { value }\end{array}$ & $\mathbf{M}$ & $\begin{array}{c}95 \% \\
\text { CI }\end{array}$ & $\begin{array}{c}P \\
\text { value }\end{array}$ & $\mathbf{M}$ & $\begin{array}{c}95 \% \\
\text { CI }\end{array}$ & $\begin{array}{c}P \\
\text { value }\end{array}$ \\
\hline Standard model (TIMI score) & 0.547 & $\begin{array}{c}0.450 \\
- \\
0.620\end{array}$ & - & Referen & - & - & Refere & - & - \\
\hline $\begin{array}{l}\text { Genotype } 66 \text { ValMet+66MetMet in } \\
\text { BDNF gene }+ \text { Standard model vs } \\
\text { Standard model }\end{array}$ & 0.709 & $\begin{array}{c}0.610 \\
- \\
0.810\end{array}$ & 0.023 & 0.31 & $\begin{array}{c}0.27 \\
- \\
0.36\end{array}$ & 0.044 & 0.068 & $\begin{array}{c}0.057 \\
- \\
0.077\end{array}$ & 0.049 \\
\hline $\begin{array}{l}\text { NT-proBNP + Standard model vs } \\
\text { Standard model }\end{array}$ & 0.697 & $\begin{array}{c}0.592 \\
- \\
0.795\end{array}$ & 0.0481 & 0.30 & $\begin{array}{c}0.22 \\
- \\
0.41\end{array}$ & 0.057 & 0.046 & $\begin{array}{c}0.020 \\
- \\
0.061\end{array}$ & 0.180 \\
\hline
\end{tabular}

Abbreviations:

AUC: Area Under Curve; IDI: integrated discrimination indices; NRI: net-reclassification improvement; CI: confidence interval

\section{Determination of genetic model variants}

We found that the model based on the genotype 66ValMet+66MetMet in BDNF gene carried out an additive value because it was defined by the following equation: OR2 $=2-1 /$ OR 1 (Table 6). This means that the regression analysis was the best fitted to the model by applying the variables which predicted cumulative clinical endpoint.

Kaplan-Meyer analysis for combined endpoint accumulation trends in post-STEMI patients

Kaplan-Meier curves demonstrated that post-STEMI patients having 66ValVal genotype of BDNF gene had the lowest accumulation of combined endpoint when compared with those who had the combination of 66ValMet and 66MetMet genotypes (Cox-criterion, $\mathrm{P}$ $=0.019$; log-rank criterion, $\mathrm{P}=0.03)$ (Figure 2).

\section{DISCUSSION}

The results of our study showed negative associations between the 66ValMet + 66MetMet polymorphisms in the BDNF gene and 6-month endpoints in post-STEMI patients. The prognostic significance of BDNF 66ValMet polymorphism was investigated in post-STEMI patients first, while these relations were previously determined in individuals with acute coronary syndrome ${ }^{35}$. Therefore, there was an association between the BDNF levels and severity of HF NYHA functional class among individuals with HF with reduced LVEF (HFrEF) ${ }^{21}$, atherosclerosis severity in stable CAD patients ${ }^{36}$, and patients with unstable angina ${ }^{37}$. The exact causes for the decline in circulating BDNF levels among patients with known CV diseases (including unstable angina, acute coronary syndrome, STEMI and HF) are uncertain. Probably, BDNF can be released from skeletal muscle, and skeletal muscle dysfunction (rather than loss of skeletal muscle mass) in HF patients may explain lowered levels of circulating BDNF in HFrEF. However, it does not determine declining levels of the peptide in postSTEMI patients with adverse cardiac remodeling, HF with preserved $\mathrm{EF}$, nor recurrent $\mathrm{CV}$ events ${ }^{38-41}$. Whether BDNF production is under control by myocardial function and exercise is not well-understood. In this context, lowered levels of BDNF have been ensured by SNP in the 66ValMet BDNF gene, which controls synthesis of the peptide ${ }^{42}$.

Previous animals and clinical trials have revealed that the BDNF levels were modulated by BDNF gene polymorphism and that $\mathrm{CV}$ actions of circulating BDNF likely correspond to this $\mathrm{SNP}^{43,44}$. Moreover, low circulating levels of BDNF were associated with adverse cardiac remodeling after STEMI and higher levels of NTproBNP ${ }^{45}$. Nevertheless, there are investigations that have yielded no close association between the genetic variants of BDNF and the serum levels of this peptide ${ }^{43,45}$. There is a hypothesis that the BDNF Val66Met genotype can affect cardiac function and $\mathrm{CV}$ risk through other mechanisms. We found an association between circulating levels of NTproBNP and BDNF gene polymorphism; however, there is no plausible evidence for the interrelation between BDNF gene polymorphism and cardiac function, severity of atherosclerosis, and CV risk factors (not including T2DM). Importantly, previous clinical 


\begin{tabular}{lccc}
\hline Table 6: Determination of genetic model variant & & & \\
\hline & ValVal & ValMet & MetMet \\
Patients who met MACEs $(\mathrm{n}=61)$ & 42 & 14 & 5 \\
Patients who did not meet MACEs $(\mathrm{n}=195)$ & 148 & 44 & 3 \\
OR1 & 1.12 & - & - \\
OR2 & 5.23 & - & - \\
\hline
\end{tabular}

Notes: OR1 = oddMm / oddMM; OR2 = oddmm / oddMm.

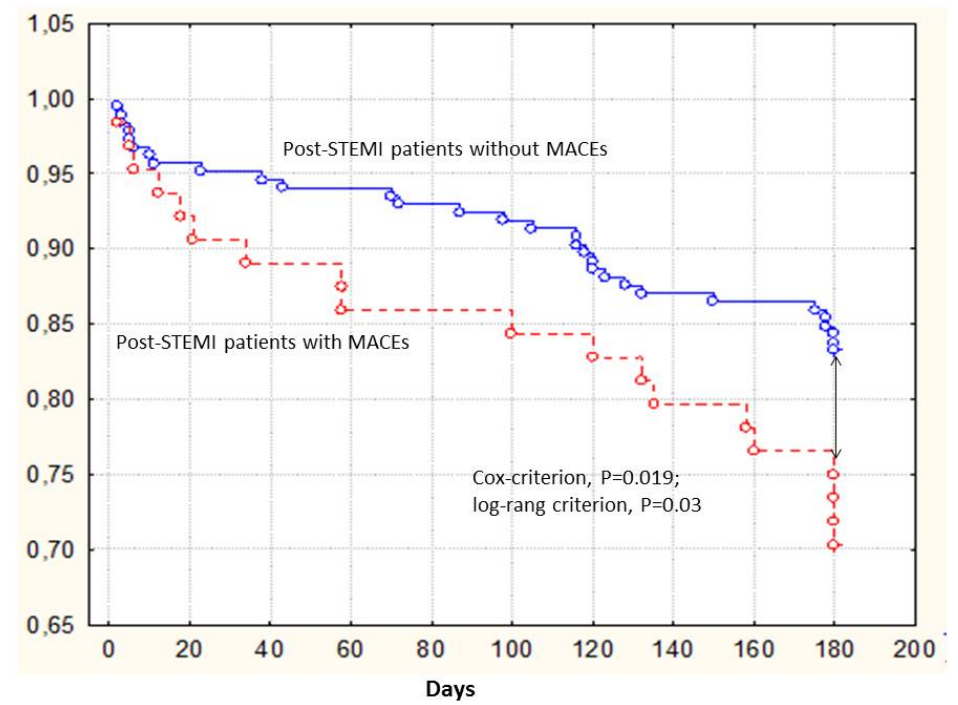

Figure 2: Kaplan-Meier curve accumulation of combined end point after 6 month observation depending on polymorphism Val66Met in BDNF gene. Notes: $1^{\text {st }}$ group: genotype $66 \mathrm{ValVal}, 2^{\text {nd }}$ group: $66 \mathrm{Val}-$ Met+66MetMet.

studies have shown associations between metabolic disease (such as morbid obesity and T2DM) and circulating levels of the BDNF, but not with the BDNF gene polymorphism ${ }^{46,47}$. Some researchers have proposed that adipocytokines can be triggers for the decline of BDNF levels, but BDNF Val66Met polymorphism has shown no significant association with circulating levels of leptin ${ }^{47}$. However, in our investigations, patients who were enrolled in these studies were not qualified as those having stable CAD or STEMI. We suggest that BDNF gene polymorphism is an independent factor contributing to MACEs and readmission to the hospital through altered cardioprotective effect. Since BDNF specifically binds to the tropomyosin-related kinase receptor B, it acts as modulator of various intracellular signaling pathways (e.g. Akt pathway, transforming growth factor-beta/ Smad pathway), which suppress inflammation and oxidative stress, upregulate the viability of ischemic tis- sue, promote differentiation of endothelial progenitor cells, and initiate neovascularization and angiogenesis in response to hypoxic and ischemia stimuli $^{48-51}$. Interestingly, the predictive values for both the BDNF Val66Met gene polymorphism and serum levels of NT-proBNP were almost similar after adjustment for severity of atherosclerosis and STEMI. Although the results of the study demonstrated that the BDNF Val66Met gene polymorphism predicted the combined endpoint in post-STEMI patients, there is no explanation for the exact molecular mechanisms which support this effect. We believe this fact is required to be investigated in the future to clearly understand primary ways that BDNF Val66Met gene polymorphism affects the clinical outcomes of postSTEMI patients after successful PPCI.

Our study had several limitations. The first limitation was associated with the small sample size, it is important to calculate sample size such that the sta- 
tistical difference between both cohorts can be discerned. However, a large clinical study is required to obtain more information regarding the BDNF gene polymorphism as a predictor for poor clinical outcomes in post-STEMI patients. The second limitation is the lack of optical coherent tomography to rule in correct expanding of stents. The third limitation relates to respectively lowered number of secondary endpoints including hospitalization due to HF, recurrent unstable angina, and STEMI and PPCI. We did not perform analysis of secondary endpoint accumulation.

\section{CONCLUSION}

We found that 66 ValMet +66 MetMet BDNF gene polymorphisms independently predicts the combined 6-month endpoint in post-STEMI patients after treatment with PPCI.

\section{ABBREVIATIONS}

ACEI: angiotensin-converting enzyme inhibitor

ARBs: angiotensin-II receptor antagonist

BDNF: brain-derived neurotrophic factor

BMI: body mass index

BP: blood pressure

CI: confidence interval

CV: cardiovascular

EF: ejection fraction

GFR: glomerular filtration rate

HCE: hypercholesterolemia

HDL: high-density lipoprotein

HF: heart failure

HR: heat rate

LAD: left atrium diameter

LAV: left atrium volume

LDL: low-density lipoprotein

LV: left ventricular

LVEDV: left ventricuar end diastolic volume

LVEF: left ventricular ejection fraction

LVESV: left ventricular end systolic volume

MACEs: major cardiovascular events

MCRA: mineralocorticoid receptor antagonist

OR: odds ratio

PPCI: primary percutaneous coronary intervention

STEMI: ST-segment elevation myocardial infarction

T2DM: type 2 diabetes mellitus

TG: triglycerides

Tn: cardiac troponin

\section{ACKNOWLEDGMENTS}

We thank all patients participated in the study and staff of the Government Institution "L.T.Malaya Therapy National Institute NAMSU" and the reperfusion center of the "Zaitsev V.T. Institute for General and Emergency Surgery NAMSU" for its assistance in the investigation. There are no previous presentations of the information reported in the article.

\section{AUTHOR'S CONTRIBUTIONS}

Olga V. Petyunina: conception of the study, protocol and study design developing, patient enrollment, data collection, statistical analysis, and writing of the article. Mykola P. Kopytsya: data collection, statistical analysis, and writing of the article. Alexander E. Berezin: data collection, statistical analysis, writing of the article and critical revision for intellectual content. All authors read and approved the final manuscript.

\section{FUNDING}

The study is a fragment of the research project: “To study the biochemical, genetic mechanisms of reperfusion damage of the myocardium and to assess the cardioprotective effect of antiplatelet therapy in acute myocardial infarction", State Registration No. 0117 U003028 / Ukraine. No commercial funds were collected for this study.

\section{AVAILABILITY OF DATA AND MATERIALS}

Data and materials used and/or analyzed during the current study are available from the corresponding author on reasonable request.

\section{ETHICS APPROVAL AND CONSENT TO PARTICIPATE}

This study was conducted in accordance with the amended Declaration of Helsinki. The institutional review board approved the study (Protocol №8, 29.08.2016), and all participants provided written informed consent.

\section{CONSENT FOR PUBLICATION}

Not applicable.

\section{COMPETING INTERESTS}

The authors declare that they have no competing interests. 


\section{REFERENCES}

1. Karayiannides S, Norhammar A, Frøbert O, James SK, Lagerqvist B, Lundman P. Prognosis in Patients With Diabetes Mellitus and STEMI Undergoing Primary PCI. J Am Coll Cardiol. 2018;72(12):1427-1428. PMID: 30213337. Available from: https://doi.org/10.1016/j.jacc.2018.06.061.

2. Paradies V, Zheng $\mathrm{H}$, Chan MHH, Chan MYY, Foo DC, Lee CW, et al. Impact of time of onset of symptom of ST-segment elevation myocardial infarction on 1-year rehospitalization for heart failure and mortality. Am Heart J. 2020;224:1-9. PMID: 32259591. Available from: https://doi.org/10.1016/j.ahj.2020. 03.011.

3. Chiara A, Clagnan E, Valent F. Epidemiology and mortality in an Italian region after the adoption of the universal definition of myocardial infarction. J Cardiovasc Med (Hagerstown). 2020;21(1):34-39. PMID: 31834103. Available from: https://doi.org/10.2459/JCM.0000000000000893.

4. Berezin AE. Circulating Biomarkers in Heart Failure. Adv Exp Med Biol. 2018;1067:89-108. PMID: 29392578. Available from: https://doi.org/10.1007/5584_2017_140.

5. El-Ahmadi A, Abassi MS, Andersson HB, Engstrøm T, Clemmensen $\mathrm{P}$, Helqvist $\mathrm{S}$, et al. Acute kidney injury - A frequent and serious complication after primary percutaneous coronary intervention in patients with ST-segment elevation myocardial infarction. PLoS One. 2019;14(12):e0226625. PMID: 31860670. Available from: https://doi.org/10.1371/journal. pone.0226625.

6. Halilčević $M$, Begić $E$, Džubur A, Šabanović-Bajramović $N$ Mekić M, Ejubović M, Džubur A, Štimjanin E. Cardiac biomarkers and left ventricular systolic function in acute myocardial infarction with ST- segment elevation in diabetes mellitus type 2 patients. Med Glas (Zenica). 2020;17(2). Available from: 10.17392/1094-20.

7. Zhang C, Liu H, Wang H, Tao Q, Lin X, Ge S, Zhai Z. The Predictive Value of Potential Hematological Biomarkers in Acute Coronary Syndrome. Clin Lab. 2019;65(10). Available from: https://doi.org/10.7754/Clin.Lab.2019.181232.

8. Lino DOC, Freitas IA, Meneses GC, Martins AMC, Daher $\mathrm{EF}$, Rocha JHC, Silva Junior GB. Interleukin-6 and adhesion molecules VCAM-1 and ICAM- 1 as biomarkers of post-acute myocardial infarction heart failure. Braz J Med Biol Res. 2019;52(12):e8658. PMID: 31778438. Available from: https: //doi.org/10.1590/1414-431x20198658.

9. Mzoughi K, Chouaieb S, Zairi I, Fredj S, Ben Kilani M, Berriri S, Zili M, Kraiem S. Prognostic value of ST2 in myocardial infarction. Tunis Med. 2019;97(2):335-343.

10. McGilligan V, Watterson S, Rjoob K, Chemaly M, Bond R, Iftikhar $A$, et al. An exploratory analysis investigating blood protein biomarkers to augment ECG diagnosis of ACS. J Electrocardiol. 2019;57S:S92-S97. PMID: 31519392. Available from: https://doi.org/10.1016/j.jelectrocard.2019.09.002.

11. Yano $\mathrm{H}, \mathrm{Chao} M V$. Neurotrophin receptor structure and interactions. Pharm Acta Helv. 2000;74:253-260. Available from: https://doi.org/10.1016/S0031-6865(99)00036-9.

12. Skaper SD. The biology of neurotrophins, signalling pathways, and functional peptide mimetics of neurotrophins and their receptors. CNS Neurol Disord Drug Targets. 2008;7(1):4662. PMID: 18289031. Available from: https://doi.org/10.2174/ 187152708783885174.

13. Kermani P, Hempstead B. Brain-derived neurotrophic factor: a newly described mediator of angiogenesis. Trends Cardiovasc Med. 2007;17(4):140-143. PMID: 17482097. Available from: https://doi.org/10.1016/j.tcm.2007.03.002.

14. Nakano I, Kinugawa S, Hori H, Fukushima A, Yokota T, Takada $S$, et al. Serum Brain-Derived Neurotrophic Factor Levels Are Associated with Skeletal Muscle Function but Not with Muscle Mass in Patients with Heart Failure. Int Heart J. 2020;61(1):96102. PMID: 31956152 . Available from: https://doi.org/10.1536/ ihj.19-400.

15. Emanueli C, Meloni M, Hasan W, Habecker BA. The biology of neurotrophins: cardiovascular function. Handb Exp Phar- macol. 2014;220:309-328. PMID: 24668478. Available from: https://doi.org/10.1007/978-3-642-45106-5_12.

16. Donovan MJ, Lin MI, Wiegn P, Ringstedt $\mathrm{T}$, Kraemer R, Hahn $\mathrm{R}$, et al. Brain derived neurotrophic factor is an endothelial cell survival factor required for intramyocardial vessel stabilization. Development. 2000;127(21):4531-4540.

17. László A, Lénárt $L$, Illésy L, Fekete $A$, Nemcsik J. The role of neurotrophins in psychopathology and cardiovascular diseases: psychosomatic connections. J Neural Transm (Vienna). 2019;126(3):265-278. PMID: 30767081. Available from: https: //doi.org/10.1007/s00702-019-01973-6.

18. Manni L, Nikolova V, Vyagova D, Chaldakov GN, Aloe L. Reduced plasma levels of NGF and BDNF in patients with acute coronary syndromes. Int J Cardiol. 2005;102(1):169-171. PMID: 15939120. Available from: https://doi.org/10.1016/j. ijcard.2004.10.041.

19. Jiang H, Liu Y, Zhang Y, Chen ZY. Association of plasma brainderived neurotrophic factor and cardiovascular risk factors and prognosis in angina pectoris. Biochem Biophys Res Commun. 2011;415(1):99-103. PMID: 22020095.

20. Costa HS, Lima MMO, Figueiredo PHS, Martinelli PM, Camargos ER, Chaves AT, et al. Prognostic value of serum brainderived neurotrophic factor levels in patients with Chagas cardiomyopathy. Mem Inst Oswaldo Cruz. 2018;113:e180224. Available from: https://doi.org/10.1590/0074-02760180224.

21. Barman HA, Şahin I, Atıcı A, Durmaz E, Yurtseven E, Ikitimur $B$, et al. Prognostic significance of brain-derived neurotrophic factor levels in patients with heart failure and reduced left ventricular ejection fraction. Anatolian journal of cardiology. 2019;22(6):309-316. Available from: https://doi.org/10.14744/ AnatolJCardiol.2019.37941.

22. Liu YQ, Su GB, Duan CH, Wang JH, Liu HM, Feng N, et al. Brain derived neurotrophic factor gene polymorphisms are associated with coronary artery disease related depression and antidepressant response. Mol Med Rep. 2014;10(6):32473253. PMID: 25324022. Available from: https://doi.org/10. 3892/mmr.2014.2638.

23. Egan MF, Kojima M, Callicott JH, Goldberg TE, Kolachana BS, Bertolino A,et al. The BDNF val66met polymorphism affects activity-dependent secretion of BDNF and human memory and hippocampal function. Cell. 2003;112(2):257-269. Available from: https://doi.org/10.1016/S0092-8674(03)00035-7.

24. Ibanez B, James S, Agewall S, Antunes MJ, Bucciarelli-Ducci C, Bueno H. et al. ESC Scientific Document Group. 2017 ESC Guidelines for the management of acute myocardial infarction in patients presenting with ST-segment elevation: The Task Force for the management of acute myocardial infarction in patients presenting with ST-segment elevation of the European Society of Cardiology (ESC). Eur Heart J. 2018;39(2):119177. PMID: 28886621. Available from: https://doi.org/10.1093/ eurheartj/ehx393.

25. Kirby A, Gebski V, Keech AC. Determining the sample size in a clinical trial. Med J Aust. 2002;177(5):256-257. PMID: 12197821. Available from: https://doi.org/10.5694/j.13265377.2002.tb04759.x.

26. Sacks DB, Arnold M, Bakris GL, Bruns DE, Horvath AR, Kirkman $M E$, et al. Guidelines and Recommendations for Laboratory Analysis in the Diagnosis and Management of Diabetes Mellitus. Diabetes Care. 2011;34(6):e61-e99. PMID: 21617108. Available from: https://doi.org/10.2337/dc11-9998.

27. Catapano AL, Graham I, De Backer G, Wiklund O, Chapman MJ, Drexel H. et al. ESC Scientific Document Group. 2016 ESC/EAS Guidelines for the Management of Dyslipidemias: The Task Force for the Management of Dyslipidemias of the European Society of Cardiology (ESC) and European Atherosclerosis Society (EAS) Developed with the special contribution of the European Association for Cardiovascular Prevention \& Rehabilitation (EACPR). Atherosclerosis. 2016;253:281-344. PMID: 27567407. Available from: https://doi.org/10.1093/eurheartj/ ehw272.

28. Williams B, Mancia G, Spiering W, Agabiti Rosei E, Azizi 
M, Burnier M. et al. ESC Scientific Document Group. 2018 ESC/ESH Guidelines for the management of arterial hypertension. Eur Heart J. 2018;39(33):3021-3104. PMID: 30165516. Available from: https://doi.org/10.1093/eurheartj/ehy339.

29. Ponikowski P, Voors AA, Anker SD, Bueno H, Cleland JGF, Coats AJS. et al. ESC Scientific Document Group. 2016 ESC guidelines for the diagnosis and treatment of acute and chronic heart failure: the task force for the diagnosis and treatment of acute and chronic heart failure of the European Society of Cardiology (ESC). Developed with the special contribution of the Heart Failure Association (HFA) of the ESC. Eur J Heart Fail. 2016;18:891-975. PMID: 27206819. Available from: https: //doi.org/10.1093/eurheartj/ehw128.

30. Morrow DA, Antman EM, Charlesworth A, Cairns R, Murphy SA, de Lemos JA, et al. TIMI Risk Score for ST-Elevation Myocardial Infarction: A Convenient, Bedside, Clinical Score for Risk Assessment at Presentation. An Intravenous nPA for Treatment of Infarcting Myocardium Early II Trial Substudy. Circulation. 2000;102:2031-2037. PMID: 11044416. Available from: https://doi.org/10.1161/01.CIR.102.17.2031.

31. Eagle KA, Lim MJ, Dabbous OH, Pieper KS, Goldberg RJ, Van WF, Goodman SG, Granger CB, Steg PG, Gore JM, Budaj A, Avezum A, Flather MD, Fox KA. A validated prediction model for all forms of acute coronary syndrome: estimating the risk of 6-month post-discharge death in an international registry. JAMA. 2004;291:2727-2733. PMID: 15187054. Available from: https://doi.org/10.1001/jama.291.22.2727.

32. Hayase M, Yoda S, Hatta T, Hori $Y$, Monno K, Fujito $H$, et al. Prognostic Significance of the Residual SYNTAX Score and Ischemic Reduction Detected with Nuclear Cardiology for Prediction of Major Cardiac Events after Revascularization. Intern Med. 2020;PMID: 32161215. Available from: https://doi.org/ 10.2169/internalmedicine.3397-19.

33. Levey AS, Stevens LA, Schmid CH, Zhang YL, Castro AF, Feldman Hl, et al, for the Chronic Kidney Disease Epidemiology Collaboration (CKD-EPI) for the CKD-EPI (Chronic Kidney Disease Epidemiology Collaboration). A New Equation to Estimate Glomerular Filtration Rate. Ann Intern Med. 2009;150:604-612. PMID: 19414839. Available from: https: //doi.org/10.7326/0003-4819-150-9-200905050-00006.

34. Horita N, Kaneko T. Genetic model selection for a case-control study and a meta-analysis. Meta Gene. 2015;5:1-8. PMID: 26042205. Available from: https://doi.org/10.1016/j.mgene. 2015.04.003.

35. Kim JM, Stewart R, Kim SY, Kim JW, Kang HJ, Lee JY, et al. Interaction between BDNF val66met polymorphism and personality on long-term cardiac outcomes in patients with acute coronary syndrome. PLoS One. 2019;14(12):e0226802. PMID: 31887219. Available from: https://doi.org/10.1371/journal. pone. 0226802 .

36. Jiang R, Babyak MA, Brummett BH, Hauser ER, Shah SH, Becker $\mathrm{RC}$, et al. Brain-derived neurotrophic factor rs6265 (Val66Met) polymorphism is associated with disease severity and incidence of cardiovascular events in a patient cohort. Am Heart J. 2017;190:40-45. PMID: 28760212. Available from: https: //doi.org/10.1016/j.ahj.2017.05.002.

37. Jiang $H$, Wang $R$, Liu $Y$, Zhang $Y$, Chen ZY. BDNF Val66Met polymorphism is associated with unstable angina. Clin Chim Acta. 2009;400(1-2):3-7. PMID: 19013140. Available from: https://doi.org/10.1016/j.cca.2008.10.017.

38. Caporali A, Emanueli C. Cardiovascular actions of neurotrophins. Physiol Rev. 2009;89(1):279-308. PMID: 19126759. Available from: https://doi.org/10.1152/physrev.00007.2008.

39. Sookaromdee $P$, Wiwanitkit V. Brain-derived neurotrophic factor as biomarker. Anatol J Cardiol. 2020;23(3):192. PMID: 32120366. Available from: https://doi.org/10.14744/
AnatolJCardiol.2020.84699.

40. Kadowaki S, Shishido T, Honda Y, Narumi T, Otaki Y, Kinoshita $D$, et al. Additive clinical value of serum brain-derived neurotrophic factor for prediction of chronic heart failure outcome. Heart Vessels. 2016;31:535-544. PMID: 25616498 Available from: https://doi.org/10.1007/s00380-015-0628-6.

41. Nakano I, Kinugawa S, Hori H, Fukushima A, Yokota T, Takada $S$, et al. Serum Brain-Derived Neurotrophic Factor Levels Are Associated with Skeletal Muscle Function but Not with Muscle Mass in Patients with Heart Failure. Int Heart J. 2020;61(1):96102. PMID: 31956152 . Available from: https://doi.org/10.1536/ ihj.19-400.

42. Sustar A, Perkovic MN, Erjavec GN, Strac DS, Pivac N. Association between reduced brain-derived neurotrophic factor concentration \& coronary heart disease. Indian J Med Res. 2019;150(1):43-49. PMID: 31571628. Available from: https: //doi.org/10.4103/ijmr.IJMR_1566_17.

43. Suriyaprom K, Tungtrongchitr R, Thawnashom K, Pimainog Y. BDNF val66Met polymorphism and serum concentrations of BDNF with smoking in Thai males. Genet Mol Res. 2013;12:4925-4933. PMID: 24301752. Available from: https: //doi.org/10.4238/2013.October.24.3.

44. Terracciano A, Piras MG, Lobina M, Mulas A, Meirelles $O$ Sutin AR, et al. Genetics of serum BDNF: Meta-analysis of the val66Met and genome-wide association study. World J Biol Psychiatry. 2013;14:583-589. PMID: 22047184. Available from: https://doi.org/10.3109/15622975.2011.616533.

45. Bahls M, Könemann S, Markus MRP, Wenzel K, Friedrich N, Nauck $M$, et al. Brain-derived neurotrophic factor is related with adverse cardiac remodeling and high NTproBNP. Sci Rep. 2019;9(1):15421. PMID: 31659205. Available from: https: //doi.org/10.1038/s41598-019-51776-8.

46. Krabbe KS, Nielsen AR, Krogh-Madsen R, Plomgaard P, Rasmussen $P$, Erikstrup $C$, et al. Brain-derived neurotrophic factor (BDNF) and type 2 diabetes. Diabetologia. 2007;50:431438. PMID: 17151862. Available from: https://doi.org/10.1007/ s00125-006-0537-4.

47. Suriyaprom K, Tungtrongchitr R, Thawnasom K. Measurement of the levels of leptin, BDNF associated with polymorphisms LEP G2548A, LEPR GIn223Arg and BDNF Val66Met in Thai with metabolic syndrome. Diabetol Metab Syndr. 2014;6:6. PMID: 24444121. Available from: https://doi.org/10.1186/1758-59966-6.

48. Feng N, Huke S, Zhu G, Tocchetti CG, Shi S, Aiba T, et al. Constitutive BDNF/TrkB signaling is required for normal cardiac contraction and relaxation. Proc Natl Acad Sci USA. 2015;112(6):1880-1885. PMID: 25583515. Available from: https://doi.org/10.1073/pnas.1417949112.

49. Hong JH, Park HM, Byun $\mathrm{KH}$, Lee BH, Kang WC, Jeong GB. BDNF expression of macrophages and angiogenesis after myocardial infarction. Int J Cardiol. 2014;176(3):1405-1408. PMID: 25129264. Available from: https://doi.org/10.1016/j.ijcard. 2014.08.019.

50. Halade GV, Ma Y, Ramirez TA, Zhang J, Dai Q, Hensler JG, Lopez EF, et al. Reduced BDNF attenuates inflammation and angiogenesis to improve survival and cardiac function following myocardial infarction in mice. Am J Physiol Heart Circ Physiol;305(12):H1830-H1842. PMID: 24142413. Available from: https://doi.org/10.1152/ajpheart.00224.2013.

51. Okada S, Yokoyama M, Toko H, Tateno K, Moriya J, Shimizu I, et al. Brain-derived neurotrophic factor protects against cardiac dysfunction after myocardial infarction via a central nervous system-mediated pathway. Arterioscler Thromb Vasc Biol. 2012;32(8):1902-1909. PMID: 22556331. Available from: https://doi.org/10.1161/ATVBAHA.112.248930. 